\title{
Alana: How One Hearing Child Used Sign Language to Move from 'Disruptive' Student to a Classroom Expert
}

\author{
Amy Brereton
}

Published online: 14 November 2008

(C) Springer Science+Business Media, LLC 2008

One of the challenges of conducting research in classrooms is deciding which stories to follow. A few years ago I spent a year investigating the effects of sign language use on hearing preschool students at a Title I school in South Carolina. The stories that emerged during my time there were rich and plentiful. This editorial focuses on one of those stories by describing the experiences of a 4 year old girl named Alana (the names of individuals, the city and the school have been changed to assure anonymity). While there is no one quite like Alana, classroom teachers may discover that Alana's struggles resemble similar difficulties faced by their students. Lawrence-Lightfoot (1998) asserts that in the particular resides the general. The exploration of the single case yields themes that are relevant to other cases. As such, Alana's story offers lessons about teaching and learning that will prove helpful in many classrooms.

\section{Alana's Learning Environment}

Alana attended morning preschool at the Palmetto School in Westchase, South Carolina. Her classroom teachers, Cindy and Katherine use a combination of Signing Exact English and spoken English in their classroom. Signing Exact English is a term used for a sign language system that represents the morphology and syntax of English but is not the same as American Sign Language (World Federation of the Deaf 1993). While Signing Exact English uses American Sign Language vocabulary, the word ordering of American Sign Language is different.

\footnotetext{
A. Brereton $(\bowtie)$

Trinity University, 125 Michigan Ave. NE,

Washington, DC 20017, USA

e-mail: abrereton45@gmail.com
}

Cindy, the lead teacher, introduced vocabulary using both spoken English and American Sign Language. For example, as children learned the English words for various shapes, colors, numbers and letters they also learned how to sign those words

\section{Barriers to Alana's Participation}

Alana was described by teachers as an outgoing child and an eager participant in all aspects of classroom life. My initial observations confirmed this description. Alana entered the classroom and immediately found an activity to get involved in. She volunteered information during circle time and chatted with the other children at her table during snack. By the third week of observations in the preschool class, I began to notice that Alana's peers frequently denied her access to their play.

As I observed Alana more closely during the weeks that followed I began to understand why the other children hesitated to interact with her. Alana was often aggressive towards her peers, using physical force to get what she wanted. Instead of asking her classmates for items she would take them. When Alana became angry or upset she lashed out, hitting, kicking, or pulling hair. Her frustrations were almost always communicated through physical aggression. Alana was also frequently violent towards classroom materials. She would rip the pages in books, tare flash cards, throw blocks, and dolls and use markers to scribble on the walls.

\section{Teachers' Concerns About Alana's Participation in the Learning Community}

Cindy's and Katherine's primary concern regarding Alana was that she would develop a negative self-image due to 
constant reprimand. The classroom teachers could not permit Alana to harm other students and it was difficult to intervene without her classmates noticing. It seemed to Katherine that she spent more time addressing Alana's negative behavior than she did praising Alana's achievements. Cindy and Katherine both feared that Alana viewed herself as a delinquent rather than as a valuable member of the classroom.

Cindy and Katherine also worried that Alana's peers would further alienate her if she did not develop communication strategies that were non-aggressive. For Alana to build friendships with the students in the class her violent behavior had to be tempered. She needed to find positive ways to communicate her desires and frustrations. By the end of the school year Alana had discovered and utilized a new and effective communication tool. That tool was sign language. The following three sections will address the ways in which using sign language contributed to an increase in participation for Alana.

\section{Alana, Sign Language and a Positive Self-Image}

Social interactions were difficult for Alana. She had to work very hard to interact with her peers in appropriate and non-aggressive ways. Many of the children in the class avoided Alana and chose not to play with her. Alana expressed a desire to have friends and showed great delight in participating in any sustained social interactions with her classmates. Unfortunately, social interactions between Alana and her peers often ended in conflict.

When Alana acted out physically towards other students, Cindy and Katherine intervened. Alana came to be known by her peers as a 'naughty girl'. Students often approached Cindy, Katherine or myself telling of how Alana had hurt them in some way. I questioned my own view of Alana when children reported Alana's wrong doings to me. If I did not see Alana hit another child and that child reported that Alana did hit her, my initial reaction was to believe that Alana had indeed been hitting. If however, that same child reported that Destin had hit someone, I would not be as likely to accept such a story. I feared that at times I reprimanded Alana unjustly simply because I readily believed accusations brought against her based on her previous behavior. When I discussed this issue with Cindy, she confessed similar worries. We were concerned that our behavior towards Alana reinforced a negative image of her. We wanted to affirm Alana's abilities publicly so that Alana, the other children and the adults in the classroom would all begin to appreciate her many strengths.

Alana was an excellent signer who was usually one of the first children to recall signs and to try new ones. Cindy, Katherine and I praised Alana's signing. She had good motor skills so she was able to make the correct hand shape for signs that some of her peers struggled with. With some prompting from Cindy, the other children permitted Alana to shape their hands into the correct shapes for various signs. She molded their hands and fingers carefully, revealing her gentleness. Through signing she was physical with her peers in a positive and helpful way.

Sign language was something that Alana succeeded at and was interested in. One morning Alana approached me and said, 'I want the big one (book) with all the signs in it!' I asked her if it was the signing dictionary that she wanted and she said, 'Yeah'. I gave her the dictionary and she flipped through the pages, trying to form the signs illustrated on them. She often asked how to sign various things. She seemed to remember signs effortlessly. Alana's signing expertise eventually reached a level where she would correct the signs used by her teachers. For example, one day Cindy signed the letter ' $x$ ' in place of the letter ' $r$ '.

Alana: This R! (Signs R)

Cindy: What did I sign?

Alana: X!

Cindy: Why I'm sorry, please excuse me. Thank you Alana.

I noticed that by February I spent more time praising Alana than I did reminding her not to be violent. I was genuinely impressed by her signing abilities. I realized that my perceptions of her were becoming more positive. Cindy and Katherine also commented on how proud they were of Alana's signing. While we still confronted her aggression, we were also given opportunities to acknowledge her achievements, particularly as a signer. Perhaps we had missed such opportunities in the past because her accomplishments were not as visible or as noticeable as sign language. We welcomed the opportunity to celebrate $\mathrm{Al}$ ana's signing expertise as but one of the strengths she possessed.

The adult members of the class were not the only ones who viewed Alana in a more positive way as the year progressed. The other children's attitudes toward Alana seemed to change as well. When the children used the picture cards to review signs, Alana would negotiate entrance into the activity and successfully participate without instances of conflict. Her social exchanges during signed activities were positive. She encouraged her peers and was praised by them for her expertise.

Alana's success as a signer helped members of the class to shift their image of her. Instead of viewing her as an aggressive classroom delinquent, or the 'naughty girl' she emerged as an expert signer, mastering signs quickly and as a gentle teacher, shaping her classmates' hands. Mastering sign language was a primary way in which Alana demonstrated her immense potential and helped members of the 
class to view her as a valuable participant in the learning of the entire group.

\section{Alana, Sign Language and Communication}

At the beginning of the year, if Alana wanted something she took it. If someone was doing something that she did not like she would usually hit, kick, pinch or bite that person. Cindy, Katherine and the other students consistently encouraged Alana to use words and not aggression to assert what she wanted. Eventually, the other children simply tried to avoid Alana. During one observation session in October, I watched Alana move from one group of children to the next attempting to join them. She would push her way into a group but was quickly told that she was not welcome there and that she should go and play some place else. In early November I observed Alana sitting on the carpet sorting colored bears. She asked four girls to play with her but each one refused. She angrily stated, "None of you is my friend!" The more that Alana was excluded the more aggressive she seemed to become.

As Alana learned more signs, however, her aggressive behavior decreased. She demonstrated less frustration and anger at school. As Alana began to use sign language more, she began to interact with her peers more appropriately. Instead of pushing another child whose behavior she did not like, she would sign "stop". The effectiveness of this method of communication (signing over physical assertion) perhaps encouraged Alana to use more signs while interacting with peers. She may have discovered that signing was usually effective while physical aggression was not.

During one session, Alana tried to take a brown crayon out of Darien's hand. There was a tugging battle over the crayon and Darien won. Alana screamed, "I want it!" Darien told her that he was using it. Again, Alana lunged for the crayon. This time Darien held it out of her reach before she got her hands on it. Alana sat staring at Darien with a wildly angry look on her face and her arms crossed over her chest. Darien soon finished his work and handed the brown crayon to Alana who was still breathless from the struggle over the crayon. After handing the crayon to Alana, Darien instructed Alana to thank him for giving it to her. Alana nodded but said nothing. "Say thank you!" Darien insisted. Alana, still fuming from the fight for the crayon, looked at Darien and signed "thank you". Darien smiled, simultaneously signed and said, "you're welcome" and moved on to the next activity. It was two full minutes before Alana's breathing slowed down and she picked up the crayon to do her work.

While observing this scene between Alana and Darien I was worried that Alana would lose her self-control and become physically aggressive towards Darien. She was learning to solve conflicts in non-physical ways but in this particular instance she was very angry and seemed unable to use her spoken words to negotiate a compromise with Darien. When Darien insisted that Alana thank him, I wondered how she would respond. Unable to speak she might find the pressure to thank Darien overwhelming adding to her already highly emotional state. I worried that she might answer his persistence with physical aggression. Alana found a more effective way to deal with the tense situation. She appeased Darien by thanking him in sign language. Satisfied Darien left Alana alone at the table and moved on to another activity. Alana then had time and space to calm down before making use of the much desired brown crayon.

Alana needed a nonverbal way to communicate when she became too emotional to communicate verbally. Sign language afforded her a way to communicate with teachers and peers effectively when she struggled to speak. This additional tool helped to reduce Alana's frustration, which led to fewer instances of physical aggression.

\section{Alana, Sign Language and Movement}

At the start of the year, Alana's participation during circle time and group instruction was hindered by classroom rules that required the children to sit still and quietly during whole class instruction unless specifically told to move or to speak by a teacher. These expectations were not limited to Cindy's class. Silent and still attention was considered a sign of respect at The Palmetto School.

Alana seemed to find sitting still especially challenging. Once again, she was the focus of a great deal of correction from teachers and peers. When she wiggled, the children sitting beside her interpreted Alana's movements as her shoving them. If she rocked her legs from side to side and accidentally touched another child with her leg, she was accused of kicking that child. Perhaps Alana's tendency to act out aggressively towards her peers resulted in them being especially sensitive and suspicious of her touch. Alana was consistently being reminded to keep her hands and feet to herself and to sit still with her hands in her lap. Alana obeyed each time but after 2 or 3 min, her body was moving again. Her attitude did not strike me as one of defiance. Sitting still for more than 3 min was just not something she was developmentally ready to do. Expecting Alana to do so set her up for failure. That Alana was not sitting still often overshadowed her efforts to contribute information during circle time and other moments of group instruction.

Sign language enabled Alana to move in an accepted way during class activities such as circle time. Cindy usually signed along with the instructions she gave during group activities. For example, when introducing a new 
letter, Cindy signed the letter and several words starting with the letter. Alana's hands moved along with Cindy as Cindy demonstrated new signs. This movement was not only permitted it was encouraged. Alana was praised for her participation. Alana needed to move. Sign language provided an acceptable means of movement for Alana during instances when the children were expected to be still.

Sign language was also a way for Alana to act out anger and frustration physically without harming her peers or classroom property. When Alana was angry she could sign words in an angry way. The following excerpt from my field journal describes an instance during which Alana used sign language as a way for her to physically vent frustration.

Excerpt from field journal:

Today Alana attempted to join Madeline, Valerie and Kaneesha in the home corner. Valerie told Alana that Katherine had said only three children could play in the home corner at a time. "So!" Alana said. Kaneesha told Alana that Alana would get into "big trouble" if she played in the home corner with them. Alana looked intensely at the three girls. I was certain that she would hit one of them or throw something. Instead she started signing rapidly and sharply. She signed "blue, brown, star, boat, car, lion, stop, help, shoe, helicopter, submarine, tie, purple". She stood there in a signing fury. It was as though she was signing whatever sign came to her mind. This was angry signing. And yet, it seemed to calm her down. Eventually her signing slowed down. She let out a breath and walked away. There was no hitting or throwing, just angry signing that did not harm or upset anyone.

During the instance described above, Alana was respectful of her need to physically express her frustration while also being respectful of the people and property around her.

\section{What Can We Learn from Alana?}

Alana's story reveals a great deal about teaching and learning. The observation and telling of Alana's story have highlighted three important lessons that we can take into other preschool classrooms. Firstly, Alana reminds us to build from children's strengths. When Alana's teachers became concerned about her behavior and her participation their first course of action was to combat their negative images of her by focusing on her abilities. Educators in Reggio Emilia, Italy communicate the importance of viewing children as strong and able, explaining that, if we have got a rich child in front of us instead of a problem child, we also become rich pedagogues and we get rich parents. The constructions we make of children influence how we relate to them' (Dahlberg, et al. 1999, p. 137). Smith (1998) argues that when a person is seen as primary and their difficulties as secondary, individuals' thinking may change to reflect a greater openness to the person and a greater optimism in regard to the amelioration of the difficulty.

As Alana's teacher's looked to affirm her strengths they discovered that her success as a signer was only one of her many abilities. Instead of viewing Alana as a 'difficult' and 'violent student', Cindy and Katherine identified Alana as a classroom expert whose contributions were valuable to the learning community. Alana, in turn appreciated her own abilities and used those abilities to increase her positive participation in the classroom.

Alana's story also reveals the need of some children to communicate non-verbally. Verbal communication can be difficult and even impossible for children during moments of intense emotion. Using sign language enabled Alana to communicate with others when speech was difficult for her. She experienced fewer instances of frustration and eventually stopped using physical aggression as a way to communicate her emotions and to vent anger. I am not suggesting that sign language is the only visual-physical communication tool that has the potential to increase participation in early years' classrooms. It is, however, a powerful option. As a natural language, sign language informs children's understandings about the nature of language. Children are also afforded the opportunity to develop vocabulary in a second language. Learning signs has the potential to increase children's participation with the many people whose primary means of communication is through sign language.

Finally, Alana's story reminds us of the importance of movement for learners. Movement is an essential part of learning and thinking. According to Hannaford (1995), every movement becomes an important link to thought processing and learning. Alana, like many children, needed more opportunities to move during instruction. The use of sign language during circle time afforded Alana a way to participate through movement. Teachers using ASL with their students have expressed that the children's hands are engaged and they seem calmer and more focused (Daniels 2001). Teachers interviewed by Hafer (unpublished dissertation, 1984) stated that during sign instruction the children were more attentive and focused because they had to look at the teacher to get the information. These teachers also noted that children seemed to respond positively to signing instruction because they were moving and active. 


\section{Final Reflection on Alana's Story}

At the start of the school year Alana's participation in classroom activities was limited. She was identified more by her physical aggression than by her abilities. Alana was excluded from play and during instances of group instruction her contributions were often overshadowed by what seemed to be an inability to sit still.

As Alana learned sign language she emerged as an expert signer. She was able to teach her peers how to construct signs and correct classroom members who used signs incorrectly. While teaching her peers and others sign language Alana was engaged in positive social interactions. She used signs rather than aggression as a physical form of communication, especially when she was highly emotional. During group instruction signing was a way for her to move without being reprimanded for not sitting still.

Alana was blessed with teachers who were committed to ensuring that each one of their students participated in all aspects of classroom life. They took the time to observe her, reflect on their own teaching practices, and develop strategies that helped to remove barriers to her participation. Let us consider for a moment what might have transpired if
Alana's teachers had not been sensitive to her needs. It is likely that she would have been labelled as a troublemaker and that this label would have followed her as she moved through compulsory education. Instead, Alana proceeded to kindergarten without such burdens. She, her classmates and her teachers focused on her abilities and viewed her as able and full of potential, which of course, she is.

\section{References}

Dahlberg, G., Moss, P., \& Pence, A. (Eds.). (1999). Beyond quality in early childhood education and care: Post-modern perspectives. London, UK: Falmer Press.

Daniels, M. (2001). Dancing with words: Signing for hearing children's literacy. Westport, CT: Bergin \& Garvey.

Hannaford, C. H. (1995). Smart moves: Why learning is not all in your head. Alexandria, VA: Great Ocean Publishers.

Lawrence-Lightfoot, S. (1998). Portraiture as method for educational research. San Diego, CA: American Research Association Annual Meeting.

Smith, J. D. (1998). Inclusion: Schools for all students. London, UK: Wadsworth Publishing Company.

World Federation of the Deaf. (1993). Report on the status of sign language. Helsinki, Finland: Miktor. 